\title{
PENERAPAN MODEL DISCOVERY LEARNING YANG BERORIENTASI HOTS DALAM PEMBELAJARAN MATERI TEKS DESKRIPSI DI KELAS VII
}

\author{
Application of HOTS-Oriented Discovery Learning Model in Description Text Materials in Class VII \\ Sakila \\ SMP Negeri 2 Singkawang \\ Jalan Pahlawan, Kota Singkawang, Indonesia \\ Pos-el: sakilaspd@yahoo.co.id
}

Naskah masuk: 4 Januari 2020; disetujui: 6 Juni 2020; revisi akhir: 22 Desember 2020

\begin{abstract}
Abstrak
Penelitian ini bertujuan untuk mendeskripsikan penerapan model discovery learning yang berorientasi HOTS pada pembelajaran menulis teks deskripsi dalam meningkatkan kemampuan siswa. Adapun rumusan masalah dalam penelitian ini adalah bagaimanakah penerapan model discovery learning yang berorientasi HOTS dalam meningkatkan keterampilan siswa pada materi pembelajaran menulis teks deskripsi. Pentingnya permasalahan ini dibahas karena pembelajaran teks deskripsi dengan menggunakan model pembelajaran sangat penting untuk dipelajari dan teks deskripsi bertujuan untuk memberikan gambaran detail tentang sesuatu atau seseorang. Penelitian ini menggunakan metode deskriptif kualitatif. Hasil penelitian menunjukkan penggunaan model discovery learning yang berorientasi HOTS meningkatkan kemampuan siswa dalam menulis teks deskripsi. Model pembelajaran discovery learning yang berorientasi HOTS dapat dijadikan salah satu alternatif untuk meningkatkan kemampuan siswa dalam pembelajaran menulis teks deskripsi.
\end{abstract}

Kata kunci: menulis, teks deskripsi, discovery learning, metode

\begin{abstract}
This study aims to describe the application of HOTS-oriented discovery learning models to learning to write descriptive text in improving students' abilities. The problematic formulation in this research is how the application of discovery learning model that is HOTS oriented in improving students' skills in learning material to write description text. The importance of this problem is discussed because learning the description text using the learning model is very important to learn and the description text aims to provide a detailed picture of something or someone. This study used descriptive qualitative method. The results showed that the use of discovery learning models that were oriented to HOTS improved the ability of students to write description texts. HOTS-oriented discovery learning model can be used as an alternative to improve students' ability in learning to write descriptive text.
\end{abstract}

Keywords: writing, description textdiscovery learning, methods

\section{Pendahuluan}

Teks deskripsi adalah salah satu materi yang terdapat pada kurikulum 2013 yang telah disusun oleh pemerintah pusat. Pembelajaran teks deskripsi ini terdapat pada semester pertama kelas VII dengan target kompetensi dasar, yakni siswa mampu mengidentifikasi informasi dalam teks deskripsi tentang objek tempat wisata yang dibaca, dan menjelaskan isi teks deskripsi objek tempat wisata yang dibaca. Dalam rangka melaksanakan tujuan pembelajaran yang dimaksud, guru sebagai seorang pendidik diharapkan mampu melaksanakan pembelajaran inovatif di kelas. Hal ini sebagaimana dikemukakan oleh Samion dan Darma (2016:3), yakni salah satu yang dapat dilakukan guru agar dalam proses pembelajaran sesuai dengan tun-tutan, maka guru harus meningkatkan kemampuan akademiknya serta selalu merespons perkembangan ilmu pengetahuan. Cara 
Sakila: Penerapan Model Discovering Learning yang Berorientasi HOTS dalam...

mengajar dengan menggunakan metode pembelajaran yang konvensional sudah seharusnya diubah dengan melakukan pendekatan atau strategi pembelajaran yang memadukan berbagai metode sesuai dengan pokok materi, yang intinya melibatkan siswa untuk berpikir kritis. Pendapat tersebut sesuai dengan tuntutan Kurikulum 2013, bahwa pembelajaran bahasa Indonesia di jenjang SMP merupakan pembelajaran yang mengintegrasikan kemampuan memahami teks, mengonstruksi teks secara kelompok, dan mengonstruksi teks secara individu.

Dalam praktik pembelajaran bahasa Indonesia di kelas, sering ditemukan beberapa kendala, yaitu capaian materi dalam pembelajaran teks deskripsi masih dikategorikan rendah. Hal ini dapat dilihat dari 32 orang siswa, persentase siswa yang mendapatkan nilai di atas KKM sebesar $50 \%$ (16 orang siswa). Sebagian lainnya siswa mendapatkan nilai di bawah kriteria ketuntasan minimal (KKM).

Berdasarkan hasil observasi dan wawancara dengan beberapa siswa, diperoleh informasi bahwa siswa cenderung malas mengikuti pembelajaran yang banyak dilakukan guru dengan cara ceramah. Selain ceramah, metode yang selalu dilakukan guru adalah penugasan. Sebagian siswa mengaku jenuh dengan tugas-tugas yang hanya bersifat teoretis dan hanya menyalin dari buku teks.

Sejalan dengan perkembangan zaman maka peserta didik harus dibekali keterampilan berpikir tingkat tinggi (higher order thinking skills). Untuk itu, penggunaan model pembelajaran yang sesuai dengan perkembangan zaman mutlak dilaksanakan oleh guru. Salah satu model pembelajaran yang berorientasi pada HOTS dan disarankan dalam implementasi Kurikulum 2013 adalah model discovery learning (pembelajaran berbasis penemuan). Selain itu, model pembelajaran berbasis masalah (problem based learning/PBL), dan project base learning ( $P j B L$ ) dapat juga dipergunakan. Dalam pelaksanaan strategi pembelajaran berbasis HOTS yang dilakukan oleh pendidik, pembelajaran akan menjadi lebih efektif karena peserta didik dihadapkan pada sua- tu permasalahan dan akan dilatih untuk mampu memecahkan masalah tersebut.

Beberapa model pembelajaran tersebut di atas, telah dilengkapi dengan urutan pembelajaran (sintak) yang sesuai dengan pelibatan siswa dalam pembelajaran. Hal ini sesuai dengan konsep pembelajaran Kurikulum 2013 yang memiliki konsep student centered (siswa lebih aktif). Selain itu, pemilihan model pembelajaran disesuaikan dengan kebutuhan pembelajaran, yang ditinjau dari kompetensi dasar, tujuan pembelajaran, dan penilaian yang akan dilaksanakan.

Teks deskripsi merupakan salah satu materi pokok dalam mata pelajaran bahasa Indonesia di kelas 7. Materi ini ditempatkan dalam kurikulum sebagai materi pertama yang diajarkan. Hal ini menunjukkan bahwa teks deskripsi memiliki keutamaan. Teks deskripsi jauh lebih mudah diajarkan dibandingkan dengan jenis-jenis teks yang lain, seperti teks narasi, teks fabel, teks laporan dan sebagainya. Selain itu, teks deskripsi bertujuan untuk memberikan gambaran detail tentang sesuatu atau seseorang sehingga hal apa pun yang diceritakan seakan-akan ada di depan mata, sehingga teman bicara dapat ikut hanyut dalam suasana tersebut. Dengan mempelajari teks deskripsi ini, diharapkan siswa menguasai kompetensi dasar untuk menyajikan data, gagasan, kesan dalam bentuk teks deskripsi tentang objek. Contohnya sekolah, tempat wisata, tempat bersejarah dan atau suasana pentas seni daerah. Teks deskripsi bersifat subjektif dan personal. Siswa dengan mudah memerinci atau melukiskan kondisi objek yang akan dideskripsikan dari sudut pandang sendiri.

Atas dasar hal tersebut, penulis tertarik untuk menelaah terkait penggunaan model discovery learning dalam rangka meningkatkan kemampuan siswa dalam pembelajaran menulis teks deskripsi serta hambatan dan solusi dalam penerapan model pembelajaran dimaksud. Adapun rumusan pernyataan penelitian ini adalah bagaimanakah penerapan model discovery learning yang berorientasi pada HOTS dalam meningkatkan keterampilan siswa menulis teks deskripsi? 
Sakila: Penerapan Model Discovering Learning yang Berorientasi HOTS dalam...

Tujuan penelitian ini adalah untuk mengetahui peningkatan keterampilan siswa menulis teks deskripsi siswa SMP pada kelas VII melalui penerapan model discovery learning yang berorientasi pada HOTS.

Adapun manfaat penelitian ini adalah sebagai berikut: (1) Bagi guru, dengan dilaksanakannya penelitian ini, guru mempunyai kemampuan untuk menerapkan model discovery learning yang berorientasi pada HOTS dalam rangka meningkatkan keterampilan siswa menulis teks deskripsi. Guru dapat meningkatkan kualitas pembelajaran yang sangat berpusat pada siswa. (2) Bagi siswa, penelitian ini bermanfaat untuk meningkatkan kemampuannya menulis teks deskripsi, bukan suatu hal yang membosankan, melainkan merupakan sesuatu yang sangat menyenangkan. (3) Bagi sekolah, penelitian ini memberikan sumbangan yang baik, pada sekolah dalam rangka perbaikan pembelajaran pada khususnya dan sekolah pada umumnya.

Penelitian mengenai teks deskripsi telah banyak dilakukan. Salah satu di antaranya adalah penelitian Setyowati (2013:130143) dengan judul "Pembelajaran Menulis Teks Deskripsi Peserta Didik Kelas VII SMP Negeri 1 Garum Berdasarkan Kurikulum 2013", yang mendeskripsikan hasil penelitiannya bahwa guru menggunakan penilaian sikap, penilaian pengetahuan, dan penilaian keterampilan yang berpedoman pada Kurikulum 2013. Selain itu, Sitohang, Syahfitri dan Siburian (2019) dengan judul penelitian "Upaya meningkatkan keterampilan menulis teks deskripsi menggunakan model pembelajaran discovery learning pada siswa kelas VII C SMP Negeri 3 Pancur Batu Tahun Pelajaran 2018/2019" menyimpulkan bahwa pada proses pembelajaran keterampilan, kualitas hasil keterampilan dan hasil pembelajaran keterampilan menulis teks deskripsi dengan menerapkan model discovery learning pada siswa kelas VII $\mathrm{C}$ mengalami peningkatan yang signifikan.

Perbedaan penelitian tersebut dengan penelitian yang dilakukan penulis adalah bahwa penelitian tersebut di atas, hanya mendeskripsikan pembelajaran menulis teks deskripsi berdasarkan penilaian kurikulum 2013, sedangkan dalam tulisan ini penulis selain mendeskripsikan pembelajaran menulis teks deskripsi juga memaparkan langkah-langkah penggunaan model discovery learning dalam pembelajaran tersebut sehingga dapat meningkatkan hasil belajar siswa di kelas VII.

Pengertian teks deskripsi menurut Darmayanti (2007:23), yaitu teks yang bertujuan menggambarkan atau melukiskan pengalaman, pendengaran, perabaan, penciuman, dan perasaan situasi atau masalah. Sejalan dengan pendapat tersebut di atas, Tim Edu Penguin (2017:147) mengemukakan bahwa teks deskripsi adalah teks yang menggambarkan tentang suatu objek (seseorang atau sesuatu). Selain pendapat tersebut di atas, Setiyaningsih dan Santhi (2019: 3) menyebutkan bahwa teks deskripsi adalah teks yang menggambarkan suatu peristiwa atau objek tentang pengalaman penglihatan, pendengaran, penciuman, dan perasaan. Selanjutnya menurut Artati (2017:4) deskripsi adalah karangan yang melukiskan sesuatu sesuai keadaan sebenarnya. Dengan demikian, pembaca dapat melihat, mendengar, merasakan hal yang dilukiskan.

Pendapat lainnya menurut Ariani dan Septiaji (2019: 49), teks yang isinya menggambarkan atau menginformasikan objek tertentu secara khusus, itulah yang dimaksud dengan teks deskripsi. Hal ini sesuai dengan pendapat Emilia dalam Ariani dan Septiaji (2019: 49) bahwa teks deskripsi merupakan teks yang memberikan informasi tentang sesuatu atau seseorang. Teks deskripsi memberi informasi mengenai topik yang dibahas dan informasi tersebut dikelompokkan pada beberapa bagian. Bagian deskripsi ini dapat diurutkan dari bagian yang paling penting sampai pada bagian yang kurang penting atau dari hal yang paling umum sampai pada hal yang khusus atau spesifik. Oshima dan Hogue dalam Ariani dan Septiaji (2019:49) juga menjelaskan bahwa teks deskripsi merupakan penulisan mengenai bentuk karakteristik hal tertentu.

Berdasarkan pemaparan di atas, teks deskripsi adalah teks yang menggambarkan hakikat objek sesuai dengan 
keadaan yang sebenarnya. Teks deskripsi melukiskan suatu objek secara menyeluruh sehingga pembaca mampu turut melihat, mencium, meraba, mendengar dan merasakan objek yang penulis deskripsikan. Hal-hal yang dapat dideskripsikan dapat meliputi orang, tempat, benda, binatang, tumbuhan, kejadian, suasana, dan lainlain. Dengan demikian, setiap hal dalam kehidupan manusia dapat dideskripsikan (Ariani dan Septiaji, 2019: 49-50).

Teks deskripsi memiliki tujuan, yakni memberi penjelasan yang utuh kepada pembacanya supaya mereka dapat memahami apa yang sedang dibicarakan dengan jelas, entah dalam hal bentuk fisik ataupun wujud yang abstrak seperti sikap, rasa dan lain sebagainya (Ariani dan Septiaji 2019: 51).

Salah satu model pembelajaran yang banyak dilakukan oleh pendidik adalah model discovery learning. Banyak pendapat yang dikemukakan oleh para ahli tentang pengertian model discovery learning. Model discovery learning menurut Darmadi (2017: 107) adalah teori belajar yang didefinisikan sebagai proses pembelajaran yang terjadi bila pelajar tidak disajikan dengan pelajaran dalam bentuk finalnya, tetapi diharapkan mengorganisasi sendiri. Hal ini sejalan dengan pendapat Bruner bahwa "Discovery learning can be defined as the learning that takes place when the student is not presented with subject matter in the final form, but rather is required to organize it him self". (Lefancois dalam Ementembun, dalam Darmadi, 2017: 107).

Sejalan dengan pendapat tersebut, menurut Budiningsih dalam Mariyaningsih dan Hidayati (2018: 66), pembelajaran discovery merupakan pembelajaran dengan memahami konsep, arti, dan hubungan melalui proses intuitif yang pada akhirnya sampai kepada suatu kesimpulan akhir. Lebih lanjut Kurniasih dan Sani (2014: 64), model discovery learning adalah proses pembelajaran yang terjadi bila pelajaran tidak disajikan dengan pelajaran dalam bentuk finalnya, tetapi diharapkan siswa mengorganisasikan sendiri. Discovery adalah menemukan konsep melalui serangkaian data atau informasi yang diperoleh melalui pengamatan atau percobaan. Ruseffendi (2006: 329), metode dis- covery learning adalah metode mengajar yang mengatur pengajaran sedemikian rupa sehingga anak memperoleh pengetahuan yang belum diketahuinya itu tidak melalui pemberitahuan, sebagian atau seluruhnya ditemukan sendiri. Selanjutnya, Hosnan (2014: 282), discovery learning adalah suatu model untuk mengembangkan cara belajar aktif dengan menemukan sendiri, menyelidiki sendiri, maka hasil yang diperoleh akan setia dan tahan lama dalam ingatan. Melalui belajar penemuan, siswa juga bisa belajar berpikir analisis dan mencoba memecahkan sendiri masalah yang dihadapi.

\section{METODE PENELITIAN}

Berdasarkan penggolongan melalui aspek metode yang dipakai, penelitian ini merupakan penelitian eksperimen. Menurut Ali (1997:59), penelitian eksperimen merupakan penelitian yang bermaksud mencari suatu keterangan dari suatu gejala atau kejadian, sehingga tidak merupakan hal yang meragukan, menyatakan sebab akibat yang sebelumnya tidak diketahui.

Penelitian ini menggunakan pendekatan kualitatif. Penelitian kualitatif merupakan salah satu metode penulisan yang menggunakan data yang berupa kata-kata tertulis atau lisan terhadap suatu objek (Arifin, 2015:172). Sementara itu, jenis penelitian adalah deskriptif. Metode deskriptif yaitu metode yang cara kerjanya lebih memberikan interpretasi, pemahaman terhadap objek yang diamati (Ratna dalam Suhardi, 2019:40). Ghony dan Almanshur dalam Suhardi (2019:40), mengemukakan bahwa "Metode deskriptif adalah metode yang cara kerjanya mendeskripsikan dan menganalisis fenomena, peristiwa, aktivitas sosial, sikap, kepercayaan, persepsi, dan pemikiran orang secara individu maupun secara kelompok". Penggunaan metode deskriptif dalam tulisan ini dimaksudkan untuk mendeskripsikan menulis teks deskripsi dengan model discovery learning yang berorientasi HOTS.

Desain penelitian yang digunakan dalam penelitian ini adalah deskriptif kualitatif. Penelitian kualitatif dengan metode deskriptif adalah penelitian yang mengidentifikasi, mengklarifikasi, menganalisis data yang telah diperoleh dan 
Sakila: Penerapan Model Discovering Learning yang Berorientasi HOTS dalam...

pendeskripsiannya berupa penggambaran bahasa sebagaimana adanya (Sudaryanto, dalam Susiati, 2018:116)

Sumber data pada penelitian ini berupa sumber data lisan dan tertulis. Sumber data lisan adalah informan yang memiliki pengetahuan tentang cara kerja peserta didik, yaitu guru sebagai pendidik. Sedangkan sumber data tertulis adalah hasil pekerjaan peserta didik kelas VII D.

Data pada penelitian ini adalah data proses dan data hasil pembelajaran peserta didik yang berupa kemampuan peserta didik dalam mengidentifikasi informasi dalam teks deskripsi tentang objek tempat wisata yang dibaca, serta menjelaskan isi teks deskripsi objek tempat wisata yang dibaca.

Teknik pengumpulan data, yang digunakan peneliti adalah teknik dokumentasi, observasi dan tes. Instrumen pengumpulan data yang digunakan dalam penelitian berupa dokumentasi, lembar observasi, dan lembar tes.

Sebelum dilakukan analisis dan penafsiran data maka keabsahan data terlebih dahulu dilakukan. Teknik pemeriksaan keabsahan data dilakukan dengan cara trianggulasi. Trianggulasi adalah teknik pemeriksaan keabsahan data yang memanfaatkan sesuatu yang lain di luar data itu untuk keperluan pengecekan atau pembanding terhadap data itu (Moleong, 2009:330).

Metode analisis data dilakukan dengan mengikuti model Miles dan Huberman dalam Sugiyono (2005:91) dengan aktivitas dalam analisis data, yaitu data reduction, data display, dan conclusion drawing/verification (reduksi data, penyajian data, penarikan kesimpulan dan verifikasi).

\section{HASIL DAN PEMBAHASAN}

\subsection{Pelaksanaan Pembelajaran Ma- teri Teks Deskripsi}

Sebagaimana telah dijelaskan bahwa tujuan penelitian ini adalah untuk mendeskripsikan penerapan pembelajaran berorientasi higher order thiking skills (HOTS) pada materi teks deskripsi. Pembelajaran teks deskripsi ini dilakukan dengan penerapan model pembelajaran discovery. Sasaran pelaksanaan penelitian ini adalah siswa kelas VII D semester 1 di
SMP Negeri 2 Singkawang sebanyak 32 orang siswa. Adapun bahan dan materi yang digunakan dalam proses pembelajaran ini adalah materi teks deskripsi kelas VII untuk pasangan Kompetensi Dasar (KD) sebagai berikut.

KD 3.1: Mengidentifikasi informasi dalam teks deskripsi tentang objek (sekolah, tempat wisata, tempat bersejarah, dan atau suasana pentas seni daerah) yang didengar dan dibaca.

KD 4.1: Menjelaskan isi teks deskripsi objek (tempat wisata, tempat bersejarah, pentas seni daerah, kain tradisional, dll) yang didengar dan dibaca secara lisan, tulis, dan visual.

Dalam pelaksanaan pembelajaran teks deskripsi, peneliti menggunakan media pembelajaran yang sesuai dengan materi yang diajarkan. Adapun media pembelajaran yang digunakan dalam penelitian ini berupa gambar tentang keberagaman wisata di Kota Singkawang dan LKPD (lembar kerja peserta didik). Sedangkan instrumen yang digunakan dalam penelitian ini berkaitan dengan teknik penilaian, yaitu (a) Sikap, Observasi (Jurnal Perkembangan Sikap) Keterampilan, Praktik (Unjuk Kerja), (c) Pengetahuan, Tes Tertulis (Soal Uraian).

\subsection{Langkah-Langkah Penerapan Strategi Pemecahan Masalah}

Dalam melaksanakan penelitian ini, digunakan cara, yaitu menerapkan pembelajaran dengan model discovery learning ( $D L)$. Berikut adalah langkahlangkah pelaksanaan yang telah dilakukan penulis.

1. Pemetaan Kompetensi Dasar

Pemetaan Kompetensi Dasar (KD) dilakukan untuk menentukan pasangan KD yang dapat diterapkan dalam pembelajaran materi teks deskripsi. Berdasarkan hasil telaah KD yang ada di kelas VII, penulis memilih pasangan KD yang pertama untuk materi teks deskripsi, yaitu KD 3.1 Mengidentifikasi informasi dalam teks deskripsi tentang objek (sekolah, tempat wisata, tempat bersejarah, dan atau suasana pentas seni daerah) yang didengar dan dibaca dan KD 4.1 Menjelaskan isi teks deskripsi objek (tempat wisata, tempa 
Sakila: Penerapan Model Discovering Learning yang Berorientasi HOTS dalam...

bersejarah, pentas seni daerah, kain tradisional, dll) yang didengar dan dibaca secara lisan, tulis, dan visual.

2. Analisis Target Kompetensi

Hasil analisis target kompetensinya sebagai berikut.

Tabel 1:

Kompetensi Dasar dan Target Kompetensi Dasar

\begin{tabular}{cl}
\hline $\begin{array}{c}\text { Kompetensi } \\
\text { Dasar }\end{array}$ & $\begin{array}{c}\text { Target Kom- } \\
\text { petensi Dasar }\end{array}$ \\
\hline 3.1 Mengidentifikasi & $\begin{array}{l}\text { Mengidentifikasi } \\
\text { informasi } \\
\text { informasi dalam }\end{array}$ \\
deskripsi & teks deskripsi \\
tentang objek & tentang objek \\
tempat wisata \\
tekolah, & yang dibaca \\
tempat wisata, & \\
bersejarah, & \\
dan atau & \\
suasana & \\
pentas seni & \\
daerah) yang & \\
didengar dan & \\
dibaca. & \\
\hline 4.1 Menjelaskan isi & Menjelaskan isi \\
teks deskripsi & teks deskripsi \\
objek (tempat & objek tempat \\
wisata, tempa & wisata yang \\
bersejarah, & dibaca \\
pentas seni & \\
daerah, kain & \\
tradisional, dll) & \\
\hline
\end{tabular}

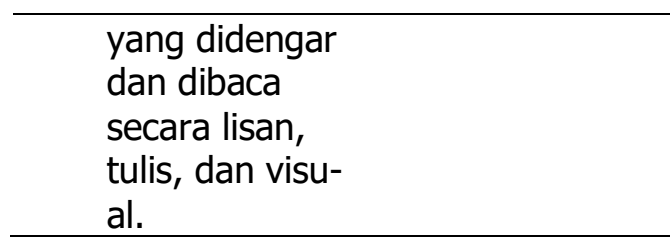

3. Perumusan Indikator Pencapaian Kompetesi.

Perumusan indikator pencapaian kompetensi pada pembelajaran menulis teks deskripsi adalah sebagai berikut.
3.1.1 Mendaftar informasi dalam teks deskripsi objek tempat wisata yang dibaca
4.1.1 Mengumpulkan informasi isi teks deskripsi objek tempat wisata yang dibaca

4. Pemilihan Model Pembelajaran

Model pembelajaran yang dipilih dalam pelaksanaan penelitian ini adalah discovery learning $(D L)$.

5. Merencanakan kegiatan pembelajaran sesuai dengan sintak model pembelajaran discovery learning $(D L)$.

Pengembangan desain pembelajaran dilakukan dengan merinci kegiatan pembelajaran yang dilakukan sesuai dengan sintak discovery learning.

Berikut ini adalah rencana kegiatan pembelajaran yang dikembangkan berdasarkan model discovery learning.

Tabel 2:

Sintak Model Pembelajaran

\begin{tabular}{|c|c|c|}
\hline $\begin{array}{l}\text { Sintak Model } \\
\text { Pembelajaran }\end{array}$ & Guru & Siswa \\
\hline $\begin{array}{l}\text { Stimulation (pem- } \\
\text { berian rangsangan) }\end{array}$ & $\begin{array}{l}\text { Menampilkan } \\
\text { gambar tentang } \\
\text { keberagaman } \\
\text { kota Singkawang } \\
\text { yang diambil dari } \\
\text { sumber internet, } \\
\text { dan menempel- } \\
\text { kan di papan tulis }\end{array}$ & $\begin{array}{l}\text { Peserta didik mengamati gambar ten- } \\
\text { tang keberagaman kota Singkawang } \\
\text { Peserta didik melakukan curah pen- } \\
\text { dapat untuk menggali pengalaman } \\
\text { mereka berkaitan dengan gambar yang } \\
\text { diamati. } \\
\text { Peserta didik merespons pertanyaan- } \\
\text { pertanyaan membangun konteks } \\
\text { berkaitan dengan gambar. }\end{array}$ \\
\hline $\begin{array}{l}\text { Problem Statement } \\
\text { (Identifikasi Masa- } \\
\text { lah) }\end{array}$ & $\begin{array}{l}\text { Pendidik } \\
\text { melakukan } \\
\text { pengamatan ter- } \\
\text { hadap aktivitas } \\
\text { peserta }\end{array}$ & $\begin{array}{l}\text { Peserta didik membaca teks deskripsi } \\
\text { tentang keindahan alam yang } \\
\text { dibagikan pendidik. } \\
\text { Secara berkelompok peserta didik } \\
\text { menerima lembar kerja peserta didik. }\end{array}$ \\
\hline
\end{tabular}


Sakila: Penerapan Model Discovering Learning yang Berorientasi HOTS dalam...

\begin{tabular}{|c|c|c|}
\hline & didik. & $\begin{array}{l}\text { 6) Pendidik melakukan pengamatan terhadap } \\
\text { aktivitas peserta didik. }\end{array}$ \\
\hline $\begin{array}{l}\text { Data Collection } \\
\text { (Pengumpulan Da- } \\
\text { ta) }\end{array}$ & $\begin{array}{l}\text { Guru memberikan } \\
\text { arahan dan cara } \\
\text { menemukan in- } \\
\text { formasi yang ter- } \\
\text { dapat di dalam } \\
\text { teks. }\end{array}$ & $\begin{array}{l}\text { 7) Peserta didik mendata lima informasi } \\
\text { sesuai dengan isi teks. }\end{array}$ \\
\hline $\begin{array}{l}\text { Data Processing } \\
\text { (Pengolahan Data) }\end{array}$ & $\begin{array}{l}\text { Membimbing dan } \\
\text { mengarahkan } \\
\text { siswa untuk } \\
\text { menemukan in- } \\
\text { formasi sesuai } \\
\text { dengan perintah }\end{array}$ & $\begin{array}{l}\text { Peserta didik secara berkelompok: } \\
\text { 8) Mendiskusikan identifikasi informasi } \\
\text { sesuai dengan isi teks. } \\
\text { 9) Menentukan hal-hal penting yang } \\
\text { terdapat dalam teks. } \\
\text { 10) Mengembangkan atau menuliskan teks } \\
\text { sesuai dengan hasil identifikasi pada } \\
\text { karton manila. } \\
\text { 11) Hasil kerja dipajang di papan pajang. }\end{array}$ \\
\hline $\begin{array}{l}\text { Verification (Pem- } \\
\text { buktian) }\end{array}$ & $\begin{array}{l}\text { Guru menilai } \\
\text { presentasi yang } \\
\text { dilakukan oleh } \\
\text { siswa }\end{array}$ & $\begin{array}{l}\text { 12) Peserta didik mempresentasikan mem- } \\
\text { berikan penjelasan-penjelasan beserta } \\
\text { alasan logis untuk membuktikan } \\
\text { kebenaran hasil identifikasi yang telah } \\
\text { didiskusikan di kelompok masing- } \\
\text { masing. } \\
\text { Setiap kelompok menempelkan hasil } \\
\text { diskusi pada tempat pajangan yang } \\
\text { disediakan. }\end{array}$ \\
\hline $\begin{array}{l}\text { Generalization } \\
\text { (Menarik Kes- } \\
\text { impulan) }\end{array}$ & $\begin{array}{l}\text { Bersama siswa } \\
\text { menyimpulkan isi } \\
\text { teks deskripsi }\end{array}$ & $\begin{array}{l}\text { 14) Peserta didik mengungkapkan kembali } \\
\text { tentang informasi yang terdapat dalam } \\
\text { teks yang telah dibaca. } \\
\text { 15) Peserta didik dan pendidik secara bersa- } \\
\text { ma-sama menyimpulkan isi teks } \\
\text { deskripsi dan dikuatkan pendidik. } \\
\text { 16) Peserta didik mengerjakan soal penilaian } \\
\text { pembelajaran yang diberikan oleh pen- } \\
\text { didik untuk mengukur ketercapaian } \\
\text { tujuan pembelajaran. }\end{array}$ \\
\hline
\end{tabular}

6. Penyusunan Perangkat Pembelajaran

Berdasarkan hasil kerja 1 hingga 5 di atas kemudian disusun perangkat pembelajaran meliputi RPP, bahan ajar, LKS, dan instrumen penilaian. RPP disusun dengan mengintegrasikan kegiatan literasi, penguatan pendidikan karakter (PPK), dan kecakapan abad 21.

Adapun langkah-langkah dalam pembelajaran materi teks deskripsi dapat dilihat pada Jurnal Praktik Mengajar yang disusun berikut. 
Tabel 3: Langkah Dalam Pembelajaran Materi Teks Deskripsi

\begin{tabular}{cl}
$\begin{array}{c}\text { Aspek Praktik } \\
\text { Pembelajaran }\end{array}$ & \multicolumn{1}{c}{ Deskripsi } \\
\hline Kegiatan Pendahuluan & $\begin{array}{l}\text { Guru melakukan pem- } \\
\text { bukaan dengan salam } \\
\text { pembuka dan berdoa un- } \\
\text { tuk memulai pembelaja- } \\
\text { ran, memeriksa kehadiran } \\
\text { siswa, menyiapkan fisik } \\
\text { dan psikis siswa dalam } \\
\text { mengawali kegiatan pem- } \\
\text { belajaran serta bersama } \\
\text { peserta didik menyanyikan } \\
\text { lagu Indonesia Raya. }\end{array}$ \\
\hline
\end{tabular}

Kegiatan Inti

1 Proses Saintifik (5M) Peserta didik mengamati gambar tentang keberagaman kota Singkawang untuk menggali pengalaman mereka dan diajak untuk menyampaikan pertanyaanpertanyaan terkait triger yang diberikan. Diharapkan muncul pertanyaan tentang mengidentifikasi

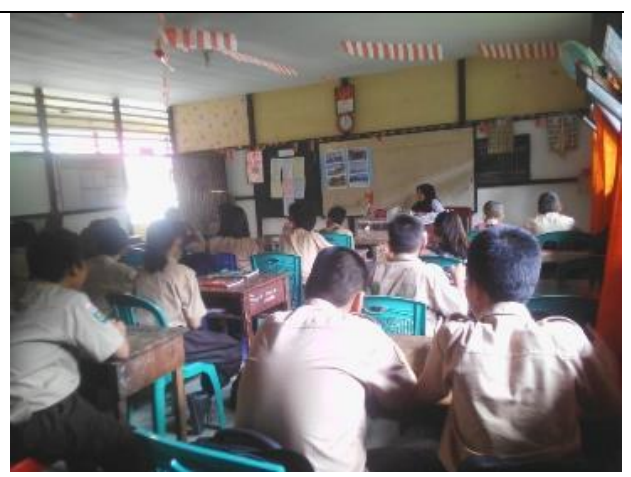
informasi teks deskripsi objek tempat wisata yang didengar dan dibaca dimaksud, serta bagaimana menentukannya.

2 Aktivitas Pembelajaran HOTS

Siswa menemukan dan menentukan hal-hal penting yang terdapat dalam teks deskripsi secara berkelompok.

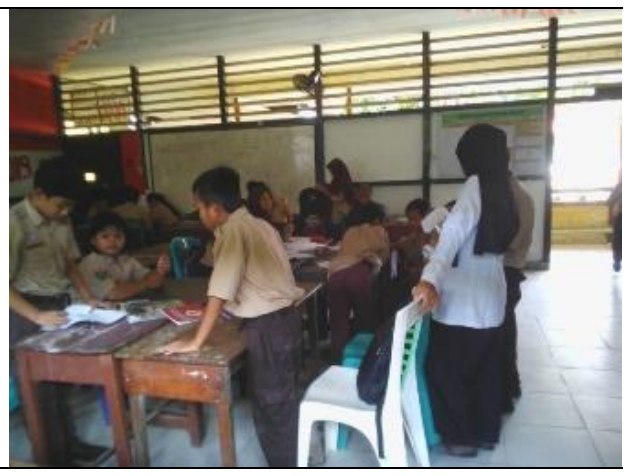


Sakila: Penerapan Model Discovering Learning yang Berorientasi HOTS dalam...

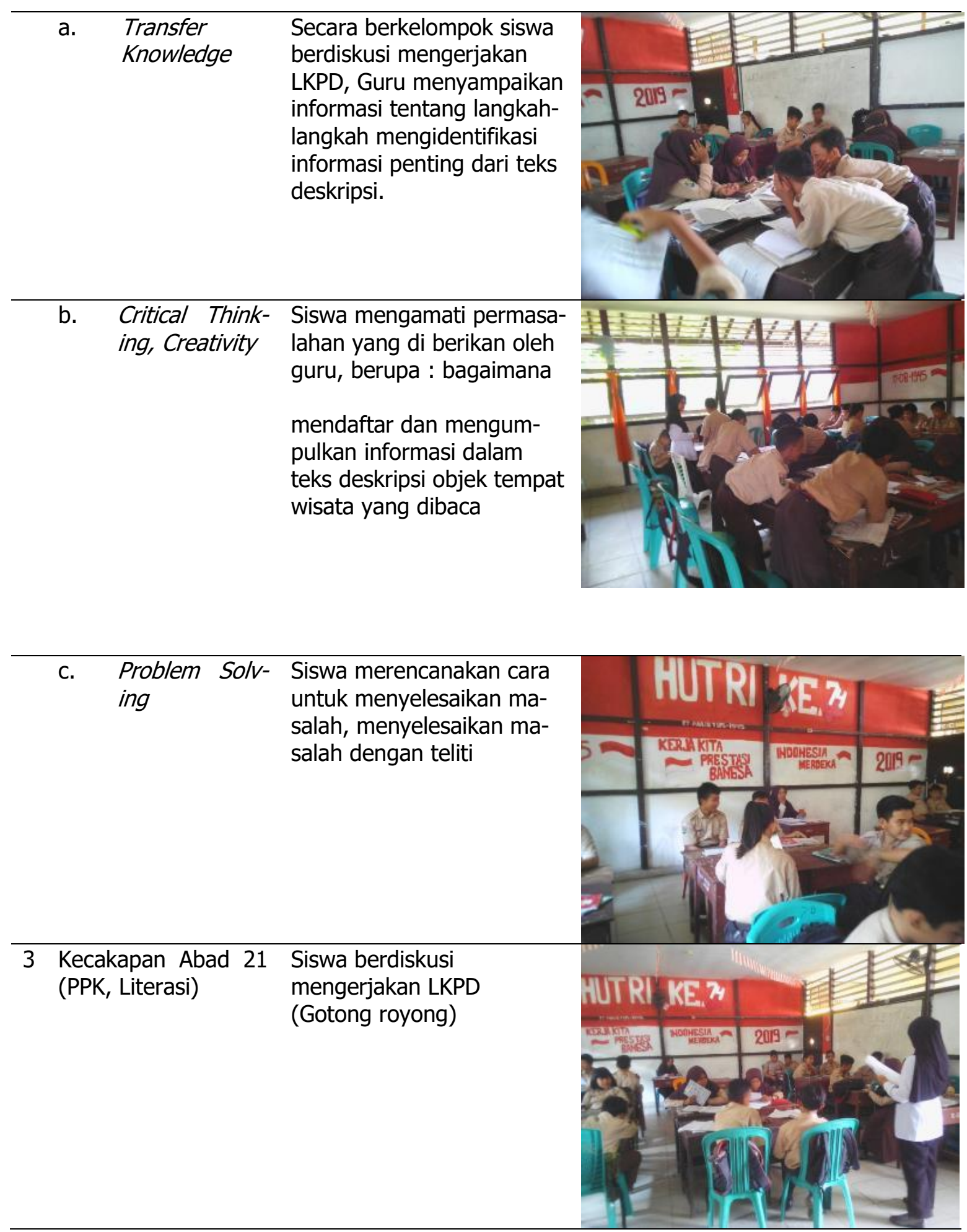




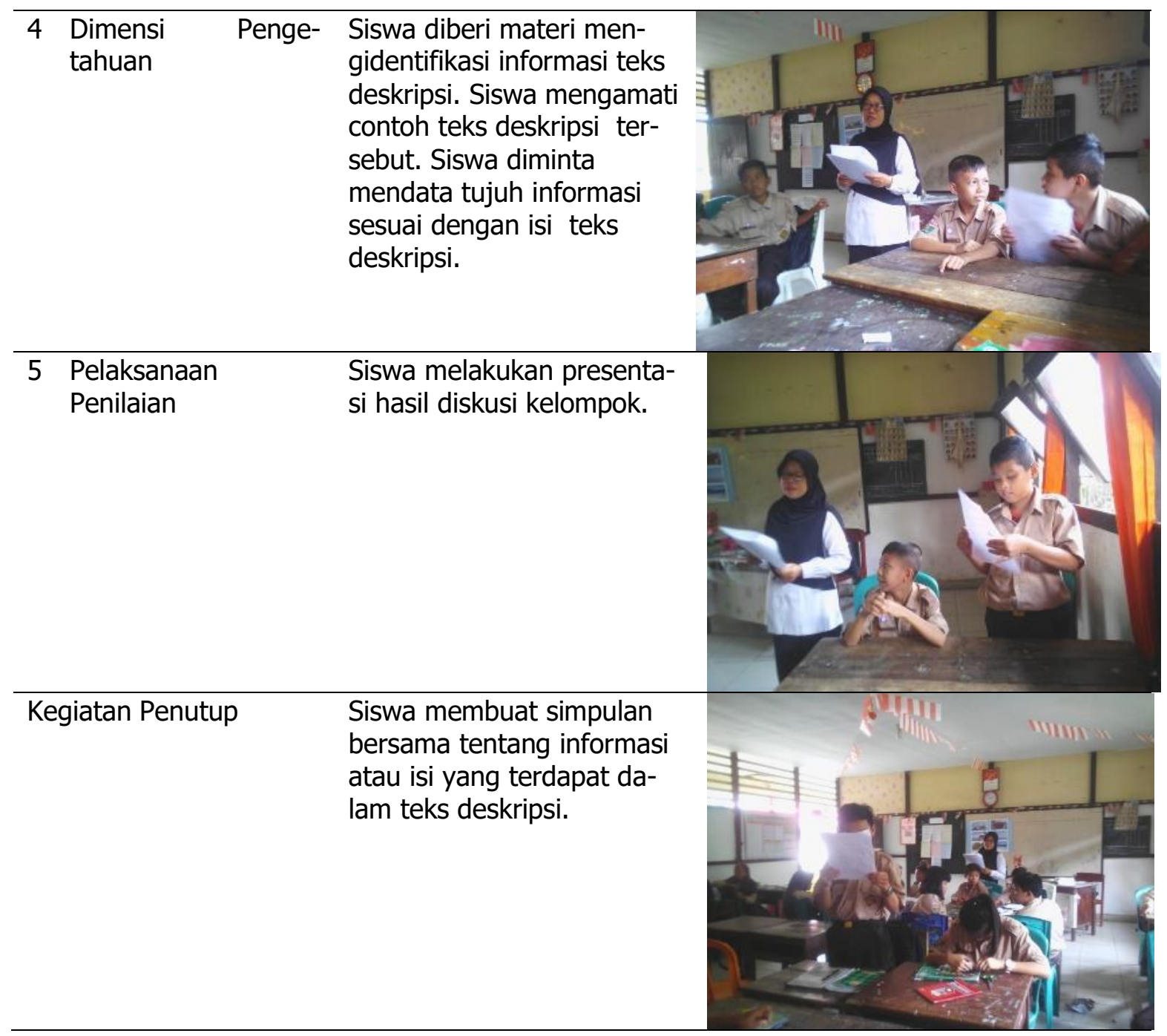

\subsection{Hasil yang Dicapai}

Adapun secara umum temuan atau hasil yang diperoleh dari pelaksanaan penelitian ini dapat diuraikan sebagai berikut:

1) Siswa terlihat aktif dalam proses pembelajaran. Hal ini dapat dilihat dari keaktifan siswa dalam merespons pertanyaan dari guru, termasuk mengajukan pertanyaan pada guru maupun temannya. Ditinjau dari proses pembelajaran pada materi teks deskripsi yang dilakukan dengan menerapkan model pembelajaran discovery learning yang berorientasi HOTS berlangsung aktif dan dapat mendorong keaktifan siswa.

2) Tingkat partisipasi siswa untuk bertanya dan menanggapi topik yang dibahas dalam pembelajaran terjadi peningkatan. Hal ini terjadi karena penerapan model discovery learning dapat meningkatkan kemampuan siswa untuk berpikir kritis. Kondisi ini berbanding terbalik pada saat pembelajaran sebelumnya. Pada saat pembelajaran yang dilakukan penulis tanpa menggunakan model discovery learning berorientasi HOTS, digambarkan suasana kelas cenderung sepi dan serius. Peserta didik cenderung bekerja sendiri-sendiri untuk berlomba menyelesaikan tugas yang diberikan guru. Materi pembelajaran teks deskripsi yang selama ini selalu disajikan diawali dengan ceramah teori tentang materi yang dipelajari, pemberian tugas, dan pembahasan (dengan pola deduktif), membuat peserta didik cenderung menghapalkan teori. Hal ini menyebabkan guru kurang peduli pada proses berpikir siswa. Kondisi ini sangat berbeda dengan 
Sakila: Penerapan Model Discovering Learning yang Berorientasi HOTS dalam...

pelaksanaan pembelajaran yang berorientasi HOTS dengan menerapkan model pembelajaran discovery learning ini. Dalam pembelajaran model ini, pemahaman siswa tentang konsep teks deskripsi benar-benar dibangun oleh siswa itu sendiri melalui pengamatan dan diskusi yang menuntut siswa mempunyai kemampuan berpikir kritis.

3) Kemampuan siswa dalam memecahkan masalah meningkat. Dengan menerapkan model pembelajaran discovery learning juga meningkatkan kemampuan siswa dalam memecahkan masalah (problem solving). Pembelajaran dengan menggunakan model discovery learning dengan menyajikan teks tulis dan gambar berupa objek wisata yang ada di Kota Singakawang diharapkan mampu mendorong siswa untuk merumuskan pemecahan masalah. Kondisi ini sangat berbeda dengan suasana pembelajaran sebelum menerapkan discovery learning. Pada pembelajaran sebelumnya, penulis melaksanakan pembelajaran sesuai dengan buku guru dan buku siswa. Jenis teks yang digunakan juga hanya pada teks tulis dari buku teks. Dengan menerapkan model discovery learning, yang berorientasi HOTS siswa tak hanya belajar dari teks tulis, tetapi juga dari media gambar tentang objek wisata Kota Singkawang yang mereka kenal serta memberikan kesempatan terbuka untuk mencari data, materi dari sumber lainnya.

Nilai siswa dalam pembelajaran menggunakan model discovery learning berorientasi HOTS menunjukkan hasil menggembirakan. Hal itu dapat dilihat pada tabel 1.

Tabel 4:

Persentase Analisis Nilai Siswa

\begin{tabular}{ccccc}
\hline Skor & $\begin{array}{c}\text { Predi- } \\
\text { kat }\end{array}$ & $\begin{array}{c}\text { Jumlah } \\
\text { Siswa }\end{array}$ & $\%$ & Ket \\
\hline $85-100$ & $\begin{array}{c}\text { Sangat } \\
\text { Baik }\end{array}$ & 26 & $\begin{array}{c}81, \\
25\end{array}$ & $\begin{array}{c}\text { Tunt } \\
\text { as }\end{array}$ \\
\hline $70-84$ & Baik & 6 & $\begin{array}{c}18, \\
75\end{array}$ & $\begin{array}{c}\text { Tunt } \\
\text { as }\end{array}$ \\
\hline $55-69$ & Cukup & 0 & - & $\begin{array}{c}\text { Tunt } \\
\text { as }\end{array}$ \\
\hline
\end{tabular}

\begin{tabular}{ccccc}
\hline $40-54$ & Kurang & 0 & $\begin{array}{c}\text { Tidak } \\
\text { Tunt } \\
\text { as }\end{array}$ \\
\hline $0-39$ & $\begin{array}{l}\text { Sangat } \\
\text { kurang }\end{array}$ & 0 & - & - \\
\hline Jumlah & Jumlah & 32 & $\begin{array}{c}10 \\
0\end{array}$ & 100 \\
\hline
\end{tabular}

Pada tabel 4 tampak bahwa dari 32 siswa, ada 26 siswa yang mendapat nilai berkategori sangat baik, dan 6 siswa berkategori baik. Hal itu menunjukkan seluruh siswa mendapat nilai dengan melebihi target ketuntasan yang telah ditetapkan sebelumnya. Keberhasilan siswa tersebut terlihat dari kemampuan siswa memenuhi target kompetensi dasar, yaitu siswa mampu mengidentifikasi informasi dalam teks deskripsi tentang objek tempat wisata yang dibaca dan menjelaskan isi teks deskripsi objek tempat wisata yang dibaca.

Hal itu sejalan dengan pendapat Roestiyah (2001:20) bahwa penggunaan metode discovery learning ini guru berusaha untuk meningkatkan aktivitas siswa dalam proses belajar mengajar. Lebih lanjut menurutnya bahwa metode discovery learning memiliki tujuan sebagai berikut: (a) Teknik ini mampu membantu siswa untuk mengembangkan, memperbanyak kesiapan, serta panguasaan ketrampilan dalam proses kognitif/pengenalan siswa, (b) Siswa memperoleh pengetahuan yang bersifat sangat pribadi/individual sehingga dapat kokoh atau mendalam tertinggal dalam jiwa siswa tersebut, (c) Dapat meningkatkan kegairahan belajar para siswa.

\subsection{Masalah yang Dihadapi}

Adapun permasalahan yang dihadapi dalam penerapan metode discovery learning adalah siswa belum terbiasa belajar dengan model discovery learning. Sehingga guru dengan segala kemampuannya berusaha untuk menerapkannya.

\subsection{Cara Mengatasi Masalah}

Berbagai cara dilakukan oleh pendidik agar siswa dapat dengan mudah menerima materi teks deskripsi. Salah satu strategi adalah penggunaan model pembelajaran discovery learning. Pembelajaran materi teks deskripsi dengan model discovery learning dapat membantu mereka lebih 
Sakila: Penerapan Model Discovering Learning yang Berorientasi HOTS dalam...

menguasai materi pembelajaran. Adapun langkah-langkah yang dilakukan oleh guru adalah pada saat memulai proses pembelajaran memberi penjelasan sekilas tentang apa, bagaimana, mengapa, dan manfaat belajar penggunaan model discovery learning yang berorientasi pada keterampilan berpikir tingkat tinggi (higher order thinking skills/HOTS). Hal ini dilakukan karena pemahaman dan kesadaran akan pentingnya penggunaan model discovery learning yang berorientasi HOTS akan membuat siswa termotivasi dan tergugah untuk mengikuti pembelajaran dimaksud. Selain itu juga penjelasan akan pentingnya kesadaran belajar bukan sekadar menghafal teori dan konsep akan membuat peerta didik mau belajar dengan model discovery learning yang berorientasi HOTS. Dengan demikian, dapat diperoleh keyakinan bahwa selain menerapkan kegiatan literasi baca-tulis, siswa juga dapat meningkatkan literasi digitalnya.

\section{SIMPULAN}

Penggunaan model discovery learning dengan berorientasi HOTS pada pembelajaran dengan materi teks deskripsi dapat meningkatkan hasil belajar siswa. Hal ini menunjukkan bahwa model pembelajaran discovery learning layak dijadikan praktik baik pembelajaran berorientasi HOTS. Hal ini disebabkan model ini dapat meningkatkan kemampuan siswa dalam melakukan transfer pengetahuan, berpikir kritis, dan pemecahan masalah.

Selain itu, guru dapat mengembangkan metode ini pada materi pembelajaran yang lain dengan media-media pembelajaran yang menarik, dan memotivasi kreativitas siswa. Guru juga diharapkan tidak hanya mengajar dengan mengacu pada buku siswa dan buku guru, namun berani melakukan inovasi pembelajaran materi teks deskripsi yang kontekstual sesuai dengan situasi, kondisi sekolahnya serta latar belakang siswa. Hal yang terpenting dan diharapkan adalah adanya dukungan dari pihak sekolah, untuk menyediakan sarana dan prasarana yang memadai serta memberikan kesempatan untuk mendesiminasikan hasil penelitian tentang pembelajaran dengan model discovery learning yang berbasis HOTS akan menambah wawasan rekan guru lain.

\section{DAFTAR PUSTAKA}

Ali, Faried. (1997). Metodologi Penelitian Sosial dalam Bidang IImu Administrasi. Jakarta: PT Raja Grafindo Persada.

Ariani, Farida dan Septiaji, Aji. (2019). Mata Pelajaran Bahasa Indonesia Sekolah Menengah Pertama (SMP) Teks Deskripsi, Cerita Imajinasi, Dan Prosedur. Jakarta: Direktorat Pembinaan Guru Pendidikan Dasar Direktorat Jenderal Guru Dan Tenaga Kependidikan, Kementerian Pendidikan Dan Kebudayaan.

Arifin, Amirah Wulansari. (2015). Problem Kejiwaan Setadewa terhadap Nasionalisme dalam Novel Burung-Burung Manyar Karya Y.B. Mangunwijaya. Jurnal Kebahasaan dan Kesastraan: Sirok Bastra, Kantor Bahasa Provinsi Bangka Belitung, Volume 3 Nomor (2):171-178.

Artati, Y. Budi. (2017). Mengarang Sebagai Proses Kreatif. Surabaya: JP Books.

Darmadi. (2017). Pengembangan Model Metode Pembelajaran dalam dinamika Belajar Siswa. Yogyakarta: Penerbit Deepublish.

Darmayanti, Nani, Adi Abdul Somad dan Nurul Hidayati. (2007). Bahasa Indonesia untuk Sekolah Menengah Kejuruan Tingkat Semenjana (Kelas X). Bandung: Grafindo Media Pratama.

Fathoni, H. Abdurahmat.(2006). Metodologi Penelitian \& Teknik Penulisan Skripsi. Jakarta:Rineka Cipta.

Hosnan, M. (2014). Pendekatan Saintifik dan Kontekstual dalam Pembelajaran Abad 21. Bogor: Ghalia Indonesia.

Kurniasih, Imas dan Sani, Berlin. (2014). Implementasi Kurikulum 2013 Konsep dan Penerapan. Surabaya: Kata Pena. 
Sakila: Penerapan Model Discovering Learning yang Berorientasi HOTS dalam...

Mariyaningsih, Nining., dan Hidayati, Mistina. (2018). Bukan Kelas Biasa: Teori dan Praktik Berbagai Model dan Metode Pembelajaran menerapkan inovasi pembelajaran di kelas-kelas inspiratif. Surakarta: CV Kekata Group.

Moleong, Lexy J. (2009). Metodologi Penelitian Kualitatif. Bandung: Remaja Rosdakarya.

Roestiyah. (2001). Strategi Belajar Mengajar. Jakarta: Rineka Cipta

Ruseffendi. (2006). Pengantar Kepada Membantu Guru Mengembangkan Kompetensinya dalam Pengajaran Matematika. Bandung: Tarsito.

Samion dan Darma, Yudi. (2016). Potret Pendidikan dan Kompetensi Guru di Daerah Perbatasan Kabupaten Sanggau. Jurnal Borneo Akcaya: Jurnal Penelitian dan Pengembangan Pelayanan Publik, Kantor Penelitian dan Pengembangan Provinsi Kalimantan Barat, Volume 3 Nomor (1):1-15.

Setiyaningsih, Ika dan Santhi Meita Sandra. (2019). Pegangan Guru Bahasa Indonesia. SMP/MTs Kelas VII Semester 1. Yogyakarta: PT Penerbit Intan Pariwara.

Setyowati, Titik. (2013). Pembelajaran Menulis Teks Deskripsi Peserta Didik Kelas VII SMP Negeri 1 Garum Berdasarkan Kurikulum 2013. Dalam Jurnal Nosi, Volume 4 Nomor 1, Pebruari 2016. Hal 130143.

Sitohang, Yohana., Syahfitri, Dian., dan Siburian, Panigoran. (2019). Upaya meningkatkan keterampilan menulis teks deskripsi menggunakan model pembelajaran discovery learning pada siswa kelas VII C SMP Negeri 3 Pancur Batu Tahun Pelajaran 2018/2019. Jurnal Darma Agung, Universitas Darma Agung, Medan, Volume XXVII, Nomor 2, Agustus 2019: $942-948$

Sugiyono. (2005). Memahami Penelitian Kualitatif. Bandung: CV Alfabeta.
Suhardi. (2019). Nilai Pendidikan Karakter Cerpen "Batu Lumut Kapas" Karya Gus TF Sakai. Jurnal Genta Bahtera: Jurnal IImiah Kebahasaan dan Kesastraan, Kantor Bahasa Kepulauan Riau Volume 5 Nomor (1):37-47.

Susiati. (2018). Homonim Bahasa Kepulauan Tukang Besi Dialek Keledupa di Kabupaten Wakatobi. Jurnal Totobuang: Jurnal Ilmiah Kebahasaan dan Kesastraan, Kantor Bahasa Maluku Volume 6 Nomor (1):109-123.

Tim Edu Penguin. (2017). Kisi-kisi Terbaru UN+USBN/MTs 2018. Jakarta: PT Grasindo. 